\title{
Dampak Penerapan Akuntansi Forensik dan Audit Investigasi dalam Mendeteksi Fraud Pengadaan Barang/Jasa
}

\author{
Retno Ratu Wiharti*, Novita Novita \\ Universitas Trilogi Jakarta, Indonesia \\ *retnoratuw@gmail.com
}

\author{
Riwayat Artikel: \\ Tanggal diajukan: \\ 5 Mei 2020 \\ Tanggal diterima: \\ 21 Mei 2020 \\ Tanggal dipublikasi: \\ 31 Agustus 2020
}

Kata kunci: Akuntansi Forensik; Audit Investigasi; Kecurangan; Pengadaan barang/jasa

\begin{abstract}
Abstrak
Penelitian ini bertujuan untuk mengetahui pengaruh penerapan akuntansi forensik dan audit investigasi dalam mendeteksi fraud pengadaan barang dan jasa. Maraknya kasus-kasus fraud yang terjadi di Indonesia, salah satunya korupsi yang berkaitan dengan kebutuhan publik yaitu pengadaan barang dan jasa. Pengumpulan data pada penelitian ini melalui penyebaran kuesioner dengan jumlah sampel sebanyak 34 responden auditor di bidang Investigasi Badan Pemeriksa Keuangan dan Pembangunan Provinsi DKI Jakarta. Penelitian ini menggunakan teknik analisis PLS (Partial Least Square), dengan menggunakan alat uji software SmartPLS versi 3.2.8. Hasil penelitian ini menunjukkan bahwa dari hasil analisis akuntansi forensik dan audit investigasi keduanya memiliki pengaruh signifikan dalam mendeteksi fraud pengadaan barang/jasa.
\end{abstract}

Pengutipan:

Wiharti, R. R., \& Novita, N. (2020). Dampak Penerapan Akuntansi Forensik dan Audit Investigasi dalam Mendeteksi Fraud Pengadaan Barang/Jasa. Jurnal Ilmiah Akuntansi dan Humanika, 10 (2), 115-125

Keywords: Forensic Accounting; Investigative Audit; Fraud; Procurement of goods and services

\begin{abstract}
The purpose of this study was to determine the effect of the forensic accounting and audit investigations in detecting fraud procurement of goods and services. The rise of fraud cases in Indonesia, one of which is fraud related to public needs, namely the procurement of goods and services. Collecting data in this study through the distribution of questionnaires with a total sample of 34 auditor respondents in the field of Investigation of the Badan Pemeriksa Keuangan dan Pembangunan DKI Jakarta. This research uses PLS (Partial Least Square) analysis technique, using SmartPLS software testing tool version 3.2.8. The results of this study indicate that the results of the analysis of the application of forensic accounting and investigative audits have a significant effect in detecting fraud procurement of goods / services.
\end{abstract}

\section{Pendahuluan}

Pada dasarnya di setiap aktivitas bisnis pasti memiliki berbagai macam risiko di dalamnya. Risiko merupakan kejadian yang tidak terduga di masa yang akan datang, risiko bersifat tidak pasti dan kemungkinannya hanya dapat diperkirakan, maka dari itu risiko yang ada harus dikelola dengan baik, karena jika mitigasi risiko dilakukan dengan kurang baik maka akan dapat menimbulkan peluang terjadinya kecurangan (fraud), serta dapat mengganggu, mencegah, dan menunda pencapaian perusahaan atau unit tujuan atau sasaran perusahaan. Jumlah fraud yang terjadi di Indonesia sepanjang tahun 2004 hingga tahun 2019 semakin meningkat jumlahnya. Kecurangan akuntansi dalam bentuk korupsi dibuktikan dengan adanya pernyataan dari Komisi Pemberantasan Korupsi bahwa telah ditemukan tindak pidana korupsi sebanyak 1007 kasus sepanjang tahun 2004 hingga tahun 2019 (Anti-Corruption Clearing House, 2019).

Kasus fraud ini telah terjadi di berbagai bidang, salah satunya termasuk dalam hal pengadaan barang/jasa di beberapa institusi pemerintah (Nisa Nurharjanti, 2017). 
Pengadaan barang dan jasa merupakan proses kesinambungan pertukaran yang menggunakan sumber daya keuangan perusahaan untuk dijadikan alat produksi (capital expenditures), yang sangat berpotensi sekali terjadi penyimpangan dan kecurangan. Pengadaan barang dan jasa publik merupakan aktivitas yang sensitif melihat dari jumlah anggaran yang sangat signifikan dan terus bertambah anggaran setiap tahunnya (Iskandar, 2013). Berdasarkan kategori penanganan kasus tindak pidana korupsi berdasarkan jenis perkara sepanjang tahun 2004 hingga tahun 2019 terdiri dari 661 perkara penyuapan, 205 perkara pengadaan barang dan jasa, 48 perkara penyalahgunaan anggaran, 34 perkara tindak pidana pencucian uang, 26 perkara pungutan, 23 perkara perizinan, dan 10 perkara merintangi proses KPK (Anti-Corruption Clearing House, 2019).

Sehubungan dengan risiko yang sangat besar dalam proses pengadaan barang dan jasa ini, mengingat dalam proses pengadaan barang/jasa sangat memerlukan pengawasan dan pemriksaan yang tepat, karena terdapat beberapa risiko dalam Pengadaan barang/jasa yaitu antara lain: kualitas pengendalian intern, besarnya nilai pengadaan barang dan jasa, tingginya tingkat risiko kegagalan pemanfaatan atas pengadaan barang dan jasa, serta kompleksitas kegiatan pengadaan barang dan jasa, yang kemungkinan besar terjadi fraud pada kegiatan pengadaan barang dan jasa dan diperkirakan memiliki pengaruh yang besar pada pencapaian tujuan pengadaan barang dan jasa. Maka dari itu perlu adanya upaya dan strategi yang tepat untuk mencegah, mendeteksi dan mengungkapkan fraud yang sangat mungkin sekali terjadi pada pengadaan barang dan jasa. Tindakan fraud yang hampir sering dijumpai pada setiap tahap dalam proses pengadaan barang/jasa mulai dari perencanaan, pembentukan panitia pengadaan, proses pengadaan, penyusunan kontrak, sampai dengan pelaksanaan kontrak (Lembaga Kebijakan Pengadaan Barang/Jasa Pemerintah, 2010). Mengingat ancaman nyata dalam fraud pengadaan barang dan jasa yang dapat menyebabkan buruknya kualitas barang/jasa yang dihasilkan sehingga tidak dapat melayani kepentingan publik secara efektif dan efisien. Dalam kondisi ini penerapan akuntansi forensik dan audit investigasi sangat dibutuhkan, akuntansi forensik merupakan penerapan disiplin akuntansi dalam arti luas, termasuk auditing pada masalah hukum untuk penyelesaian hukum di dalam atau di luar pengadilan (Tuanakotta, 2016), dan sedangkan keterampilan audit Investigasi dibutuhkan untuk mengumpulkan bukti, menganalisis bukti, mengevaluasi bukti, menafsirkan dan mengkomunikasikan hasil temuan kemungkinan terjadinya (ada atau tidaknya) pelanggaran/perbuatan melawan hukum.

Sesuai dengan penelitian yang dilakukan oleh (Fauzan, Purnamasari, \& Gunawan, 2014) yang menyimpulkan bahwa akuntansi forensik serta audit investigasi berpengaruh sangat baik secara parsial maupun simultan terhadap pengungkapan fraud. Serta sejalan dengan penelitian lainnya yang dilakukan oleh (Rizki, Purnamasari, \& Oktaroza, 2017) menyatakan bahwa akuntansi forensik dan audit investigasi masing-masing memiliki efek positif yang signifikan pada deteksi kejahatan kerah putih (White Collar Crime). Maka dari itu penerapan Akuntansi forensik dan Audit Investigasi sangat dibutuhkan dalam upaya mendeteksi Fraud (Wawolangi, 2014) karena perkembangan fraud yang semakin pesat dari hari ke hari. Hal ini dapat membantu untuk mengurangi kasus fraud seperti korupsi yang sering terjadi di Lingkungan Pemerintahan, serta dapat mengembalikan dan meningkatkan kepercayaan publik kepada pemerintahan.

Berdasarkan uraian diatas penelitian ini bertujuan untuk melihat akan pengaruh penerapan akuntansi forensik dan audit investigasi dalam mendeteksi fraud, namun yang membedakan dengan studi sebelumnya fraud dalam konteks ini ialah yang terjadi pada pengadaan barang/jasa. Badan Pengawasan Keuangan dan Pembangunan (BPKP) dipilih karena salah satu tugas dari bidang investigasi BPKP adalah melaksanakan akuntansi forensik dan audit investigasi terhadap kasus-kasus penyimpangan/melanggar hukum (fraud) yang merugikan keuangan negara. Dengan demikian penelitian ini diharapkan mampu memberikan manfaat, saran dan masukan dalam upaya peningkatan kinerja, kualitas, sikap profesional selaku para akuntan forensik dan audit Investigasi yang bekerja di Badan Pengawasan Keuangan dan Pembangunan (BPKP) khususnya pada BPKP Provinsi DKI Jakarta, untuk dapat memberi kontribusi dalam melakukan pengembangan hasil temuan bukti fraud (kecurangan) kepada pihak yang membutuhkan, sehingga penuntasan kasus- 
kasus fraud (kecurangan) dapat terselesaikan khususnya yang berkaitan dengan fraud pengadaan barang/jasa.

Akuntansi forensik merupakan penerapan disiplin akuntansi dalam arti luas, termasuk auditing yang memiliki prospek yang sangat bagus untuk mendeteksi fraud terutama dalam pencegahan dan pemberantasan tindak pidana korupsi dalam konteks ini adalah fraud pengadaan barang dan jasa. Dimana hasil dari penerapan akuntansi forensik dapat dijadikan sebagai alat bukti atau litigation support di pengadilan hukum dengan mendeteksi, memeriksa, dan mengungkapkan adanya fraud yang dapat digunakan dalam proses pengambilan putusan di pengadilan (Tuanakotta, 2016). Dengan adanya akuntansi forensik, akuntan forensik dapat melakukan perhitungan dan mengungkapkan pos kecurangan, mendeteksi penyebab terjadinya kecurangan, menemukan petunjuk awal (indicia of fraud) terjadinya kecurangan, dan mendeteksi kira-kira waktu kecurangan dapat terungkap serta membedakan kecurangan yang terungkap akibat kecurangan-kecurangan tersebut (Jumansyah, 2011). Penelitian yang menjadi dasar dalam penelitian ini yaitu penelitian yang dilakukan oleh (Rizki et al., 2017), menyimpulkan bahwa akuntansi forensik dan investigasi audit memiliki efek positif yang signifikan pada deteksi kejahatan kerah putih (White Collar Crime). Berdasarkan penjelasan tersebut penelitian ini menggunakan hipotesis 1 sebagai berikut:

\section{$\mathrm{H}_{1}$ : Penerapan Akuntansi forensik berpengaruh dalam mendeteksi fraud dalam pengadaan barang/jasa.}

Sedangkan dalam rangka memperkecil kerugian akibat fraud dan memperbaiki sistem pengendalian jika terdapat indikasi kuat terjadinya fraud, maka langkah yang tepat untuk melakukan audit investigasi dalam mendeteksi fraud dalam konteks ini pengadaan barang dan jasa. Istilah Audit Investigatif muncul dalam Undang-Undang No. 15 Tahun 2004 tentang Pemeriksaan Pengelolaan dan Tanggung Jawab Keuangan Negara yang menjelaskan bahwa "audit investigatif termasuk dalam pemeriksaan dengan tujuan tertentu, yaitu pemeriksaan yang dilakukan dengan tujuan khusus, di luar pemeriksaan keuangan dan kinerja". Dengan melakukan penerapan audit investigatif dilengkapi dengan pengetahuan dan keterampilan audit investigatif, seperti taktik pengawasan, wawancara, dan keahlian interogasi, membantu akuntan forensik memiliki keterampilan lain di luar keterampilan yang berkaitan dengan audit dan mampu memadukan dengan aspek keuangan dan hukum. Hasil Penelitian sebelumnya yang menjadi dasar penelitian ini ialah penelitian yang dilakukan oleh (Ardiansyah, et al., 2016) mengungkapkan bahwa Audit investigasi berpengaruh signifikan terhadap pendeteksian fraud. Berdasarkan penjelasan tersebut penelitian ini menggunakan hipotesis 2 sebagai berikut:

\section{$\mathrm{H}_{2}$ : Penerapan Audit Investigasi berpengaruh dalam mendeteksi fraud dalam pengadaan barang/jasa.}

\section{Metode}

Jenis penelitian ini merupakan kajian dasar yang menggunakan metode verifikatif yaitu penelitian yang dilakukan kembali berdasarkan penelitian sebelumnya untuk memastikan dan memberikan hasil yang lebih update berdasarkan keadaan sesungguhnya. Dalam penelitian ini yang dimaksud dengan populasi adalah objek yang berkaitan dengan pendeteksian fraud pengadaan barang dan jasa yaitu Auditor di Bidang Investigasi yang terdapat pada Perwakilan BPKP Provinsi DKI Jakarta. Bidang Investigasi Badan Pengawasan Keuangan dan Pembangunan (BPKP) dipilih karena salah satu tugas dari bidang investigasi BPKP adalah melaksanakan akuntansi forensik dan audit investigasi terhadap kasus-kasus penyimpangan/melanggar hukum (fraud) yang merugikan keuangan negara. Populasi penelitian ini adalah auditor Investigasi di Perwakilan BPKP Provinsi DKI Jakarta, berdasarkan teknik penentuan sampel penelitian ini menggunakan nonprobability sampling dengan teknik purposive sampling dan sampel jenuh yaitu seluruh auditor Bidang Investigasi di Perwakilan BPKP Provinsi DKI Jakarta yang berjumlah 34 orang auditor dengan kriteria auditor yang memiliki pengalaman dalam melaksanakan akuntansi forensik dan audit investigasi. 
Pada penelitian ini, Sumber data yang digunakan dalam penelitian ini memakai sumber data internal yang didapatkan dari dalam organisasi berupa data primer. Data primer dalam penelitian ini diperoleh melalui kuesioner yang dibagikan kepada responden kepada seluruh Auditor Investigasi di Badan Pengawasan Keuangan dan Pembanlgunan (BPKP) DKI Jakarta. Data yang diperoleh dari responden melalui kuesioner akan dianalisis menggunakan analisis verifikatif. Analisis verifikatif merupakan analisis untuk membuktikan dan mencari kebenaran dari hipotesis yang digunakan dalam penelitian ini dengan menggunakan metode Partial Least Square (PLS), melalui alat uji statistik yaitu Model Persamaan Struktural (Structural Equation Model - SEM) berbasis variance, analisis ini dilakukan dengan menggunakan SmartPLS versi 3.2.8. Analisis verifikatif terdiri dari tiga tahap yaitu pengukuran outer model, evaluasi model struktural (Inner model), dan pengujian hipotesis.

\section{Hasil dan Pembahasan}

Analisis verifikatif terdiri dari tiga tahap yaitu pengukuran outer model, evaluasi model struktural (Inner model), serta pengujian hipotesis, pada bagian selanjutnya merupakan penjelasannya sebagai berikut:

\section{Analisis Outer Model}

Analisis outer model digunakan untuk memastikan bahwa measurement yang digunakan layak untuk dijadikan pengukuran (valid dan reliabel). Analisis outer model dapat dilihat dari beberapa indikator, yaitu convergent validity, discriminant validity, dan unidimensional/reliability (Ghozali, 2015). Analisis outer ini menspesifikasikan hubungan antar variabel dengan indikator-indikatornya, atau dapat dikatakan bahwa outer model mendefinisikan bagaimana setiap indikator berhubungan dengan variabelnya dan digunakan untuk menguji validitas dan reliabilitas data. Pengukuran outer model meliputi beberapa tahapan yang dijelaskan berdasarkan data dari responden penelitian dengan hasilnya sebagai berikut:

1) Uji Validitas

a) Convergent validity, pada evaluasi outer model dengan indikator reflektif dapat dilihat dari korelasi nilai item/indikator dengan nilai konstruknya. Untuk lebih jelasnya dapat dilihat hasil output korelasi antara indikator dengan konstruknya pada Tabel 1 berikut ini:

Tabel 1. Outer Loading

\begin{tabular}{clc}
\hline Variabel & \multicolumn{1}{c}{ Indikator } & Outer loadings \\
\hline \multirow{2}{*}{ Akuntansi Forensik } & Kualitas akuntansi forensik & $\mathbf{0 . 9 3 2}$ \\
& Standar Akuntansi Forensik & $\mathbf{0 . 7 8 7}$ \\
& Kemampuan Audit Investigasi & $\mathbf{0 . 9 2 8}$ \\
Audit Investigasi & Standar Audit Investigasi & $\mathbf{0 . 8 0 7}$ \\
& Identifikasi Gejala Fraud & $\mathbf{0 . 8 1 0}$ \\
Fraud Pengadaan & Teknik Mendeteksi Fraud & $\mathbf{0 . 9 5 6}$ \\
\hline
\end{tabular}

Sumber: Pengolahan data dengan SmartPLS versi 3.2.8, 2020

Hasil convergent validity berdasarkan pada Tabel 1 menunjukkan bahwa nilai outer loading dari variabel akuntansi forensik yang meliputi: indikator kualitas akuntansi forensik dengan nilai outer loading sebesar 0,932 dan indikator standar akuntansi forensik dengan nilai outer loading sebesar 0,787, lalu, variabel audit investigasi yang meliputi: indikator kemampuan/keahlian audit investigasi nilai outer loading-nya sebesar 0,928, dan indikator standar audit investigasi nilai outer loading-nya sebesar 0,807 , serta nilai outer loading dari variabel pendeteksian fraud Pengadaan 
Barang/Jasa yang mencakup: indikator identifikasi gejala fraud dengan nilai outer loading 0,810 dan indikator teknik mendeteksi fraud dengan nilai outer loading 0,956. Dengan demikian perolehan data yang telah diuji menunjukkan nilai outer loading yang telah sesuai kriteria untuk memenuhi syarat convergent validity, tidak ada indikator variabel yang nilai outer loading-nya di bawah 0,70 , sehingga semua indikator dinyatakan layak atau valid untuk digunakan penelitian dan dapat digunakan untuk analisis lebih lanjut.

b) Discriminant Validity dapat memperlihatkan sejauh mana sebuah konstruk laten mendiskriminasikan dirinya dengan konstruk laten lainnya. Untuk mengetahui lebih lanjut dapat dilihat pada Tabel 2 dimana keseluruhan indikator setiap masing-masing variabel menunjukkan nilai loading factor yang lebih tinggi dibandingkan dengan nilai loading factor indikator terhadap variabel lainnya. Sajian data pada Tabel 2 berikut ini menunjukkan bahwa masing-masing indikator pada variabel penelitian memiliki nilai loading factor terbesar pada variabel yang dibentuknya dibandingkan dengan nilai loading factor pada variabel lainnya. Berdasarkan hasil yang diperoleh tersebut, dapat dinyatakan bahwa indikator-indikator yang digunakan dalam penelitian ini telah memiliki discriminant validity yang baik dalam menyusun variabelnya masing-masing dan menunjukkan bahwa konstruk laten memprediksi indikator pada bloknya lebih baik dibandingkan dengan indikator di blok lainnya.

Tabel 2. Cross Loading

\begin{tabular}{lccc}
\hline \multicolumn{1}{c}{ Indikator } & \multicolumn{3}{c}{ Variabel } \\
\cline { 2 - 4 } & $\begin{array}{l}\text { Akuntansi } \\
\text { Forensik }\end{array}$ & $\begin{array}{c}\text { Audit } \\
\text { Investigasi }\end{array}$ & $\begin{array}{c}\text { Fraud } \\
\text { Pengadaan } \\
\text { Barang/Jasa }\end{array}$ \\
\hline $\begin{array}{l}\text { Kualitas akuntansi } \\
\text { forensik }\end{array}$ & 0,932 & 0,512 & 0,638 \\
$\begin{array}{l}\text { Standar Akuntansi } \\
\text { Forensik }\end{array}$ & 0,787 & 0,386 & 0,375 \\
$\begin{array}{l}\text { Kemampuan Audit } \\
\text { Investigasi }\end{array}$ & 0,601 & 0,928 & 0,772 \\
$\begin{array}{l}\text { Standar Audit Investigasi } \\
\text { Identifikasi Gejala Fraud }\end{array}$ & 0,255 & 0,807 & 0,487 \\
Teknik Mendeteksi Fraud & 0,696 & 0,379 & 0,810 \\
\hline \multicolumn{1}{l}{ Sumber Pengolanan } & 0,833 & 0,956 \\
\hline
\end{tabular}

Sumber: Pengolahan data dengan SmartPLS versi 3.2.8, 2020

c) Nilai Average Variant Extracted merupakan cara lain untuk dapat menilai validitas dari konstruk, untuk masing-masing indikator di persyaratkan nilainya harus $>0,5$ untuk model yang baik.

Tabel 3. Average Variant Extracted

\begin{tabular}{lc}
\hline \multicolumn{1}{c}{ Variabel } & Average Variance Extracted (AVE) \\
\hline Akuntansi Forensik & $\mathbf{0 , 7 4 4}$ \\
Audit Investigasi & $\mathbf{0 , 7 5 6}$ \\
Fraud Pengadaan Barang/Jasa & $\mathbf{0 , 7 8 4}$ \\
\hline \multicolumn{2}{c}{ Sumber: Pengolahan data dengan SmartPLS versi 3.2.8, 2020 }
\end{tabular}

Berdasarkan sajian data dalam Tabel 3 di atas, diketahui bahwa nilai average variant extracted (AVE) pada variabel Akuntansi forensik, Audit investigasi dan pendeteksian fraud pengadaan barang dan jasa telah melampaui nilai kriteria AVE yaitu $>0,5$. 
Dengan demikian dapat dinyatakan bahwa antara indikator dengan konstruknya lebih dari 0,50 yang artinya, korelasi antar indikator dapat disimpulkan sangat baik dan memiliki nilai average variant extracted yang baik pada setiap konstruknya sehingga dapat disimpulkan bahwa rata-rata tingkat eror lebih rendah.

2) Uji Reliabilitas

Composite Reliability merupakan bagian yang digunakan untuk menguji nilai reliabilitas indikator-indikator pada suatu variabel. Suatu variabel dapat dinyatakan memenuhi composite reliability apabila memiliki nilai composite reliability $>0,6$. Uji reliabilitas lainnya dapat menggunakan nilai Cronbach alpha untuk memperkuat uji reliabilitas atas nilai composite reliability. Suatu variabel dapat dinyatakan reliabel atau memenuhi Cronbach alpha apabila memiliki nilai Cronbach alpha $>0,7$. Berikut ini adalah nilai composite reliability dan nilai Cronbach alpha dari masing-masing variabel yang digunakan dalam penelitian ini:

Tabel 4. Composite Reliability \& Cronbach's Alpha

\begin{tabular}{lcc}
\hline \multicolumn{1}{c}{ Variabel } & Cronbach's Alpha & Composite Reliability \\
\hline Akuntansi Forensik & $\mathbf{0 , 6 7 4}$ & $\mathbf{0 , 8 5 2}$ \\
Audit Investigasi & $\mathbf{0 , 6 9 2}$ & $\mathbf{0 , 8 6 1}$ \\
Fraud Pengadaan Barang/Jasa & $\mathbf{0 , 7 5 1}$ & $\mathbf{0 , 8 7 8}$ \\
\hline \multicolumn{2}{c}{ Sumber: Pengolahan data dengan SmartPLS versi 3.2.8, 2020 }
\end{tabular}

Berdasarkan sajian data pada tabel 4 di atas, dapat diketahui bahwa nilai composite reliability semua variabel penelitian $>0,6$. Hasil ini menunjukkan bahwa masing-masing variabel telah memenuhi composite reliability yang tergolong sangat memuaskan, sehingga dapat disimpulkan bahwa keseluruhan variabel memiliki tingkat reliabilitas yang tinggi. Sedangkan pada tabel 4 diatas menunjukkan bahwa masih terdapat indikator yang memiliki nilai Cronbach alpha tidak sesuai kriteria atau di bawah 0,70 yaitu indikator Akuntansi forensik sebesar 0,674 dan Audit Investigasi sebesar 0,692. Namun indikator tersebut masih dapat diuji karena berdasarkan Haryono (2017) persyaratan nilai internal consistency reliability yaitu $>0,6$ dan nilai yang terdapat pada tabel 4 Cronbach alpha telah menginterpretasi reliabilitas data yang masih dapat diterima. Dengan demikian hasil ini dapat menunjukkan bahwa masing-masing variabel penelitian telah memenuhi persyaratan nilai internal consistency reliability. Dan dapat disimpulkan bahwa instrumen dari kuesioner yang digunakan untuk menjelaskan variabel akuntansi forensik, audit investigasi, dan fraud pengadaan barang/jasa yaitu dinyatakan handal atau dapat dipercaya sebagai alat ukur variabel.

\section{Analisis Inner Model}

Analisis inner model atau analisis model struktural dilakukan untuk memastikan bahwa model struktural yang dibangun akurat. Evaluasi inner model dapat dilihat dari beberapa indikator meliputi path coefficient, koefisien determinasi (R2) dan predictive relevance (Q2) (Ghozali, 2015). Berikut merupakan penjelasan hasil dari pengujian model struktural, yaitu:

1) Path Coefficient,

Nilai Path Coefficient dapat dilihat pada Tabel 5 yang menunjukkan bahwa konstruk pengaruh variabel penerapan akuntansi forensik dalam pendeteksian fraud pengadaan barang/jasa memiliki nilai sebesar 0.302 , dan pengaruh variabel penerapan audit investigasi dalam pendeteksian fraud pengadaan barang/jasa sebesar 0,591. Berdasarkan uraian hasil tersebut, keseluruhan variabel dalam model ini memiliki nilai path coefficient dengan angka yang positif atau variabel konstruk penerapan akuntansi forensik dan penerapan audit investigasi memiliki pengaruh positif terhadap pendeteksian fraud pengadaan barang dan jasa. 
Tabel 5. Path Coefficient

\begin{tabular}{lc}
\hline \multicolumn{1}{c}{ Variabel } & Fraud Pengadaan Barang Dan Jasa \\
\hline Akuntansi Forensik & 0,302 \\
Audit Investigasi & 0,591 \\
\hline Sumber: Pengolahan data dengan SmartPLS versi 3.2.8, 2020
\end{tabular}

\section{2) R Square}

Nilai $R$ Square $\left(R^{2}\right)$ untuk konstruk endogen yaitu pendeteksian fraud pengadaan barang dan jasa $(\mathrm{Y})$. Berdasarkan Tabel 6 , nilai $R$ Square menunjukkan nilai sebesar 0,630 sehingga memiliki hubungan yang moderat karena nilai $R$ Square $>0,33$. Artinya, sebesar $63 \%$ variabel Fraud Pengadaan Barang dan Jasa dapat dipengaruhi oleh variabel Akuntansi forensik dan Audit investigasi dan sisanya sebesar 37\% dipengaruhi oleh variabel lain yang tidak digunakan dalam penelitian ini.

Tabel 6. R Square

\begin{tabular}{cll}
\hline Variabel & R Square & R Square Adjusted \\
\hline Fraud Pengadaan Barang dan Jasa & $\mathbf{0 , 6 3 0}$ & 0,606 \\
\hline \multicolumn{2}{l}{ Sumber: Pengolahan data dengan SmartPLS versi 3.2.8, 2020 }
\end{tabular}

\section{3) Predictive relevance}

Nilai ini didapatkan dengan cara melihat jalur redundansi validasi-silang konstruk dengan menggunakan prosedur blindfolding. Uji ini dilakukan untuk mengevaluasi inner model dan mengetahui kapasitas prediksi variabel yang diteliti pada estimasi parameter konstruk. Kriteria penilaiannya, yaitu 0.02 (kecil), 0.15 (sedang), dan 0.35 (besar) (Ghazali \& Laten, 2015).

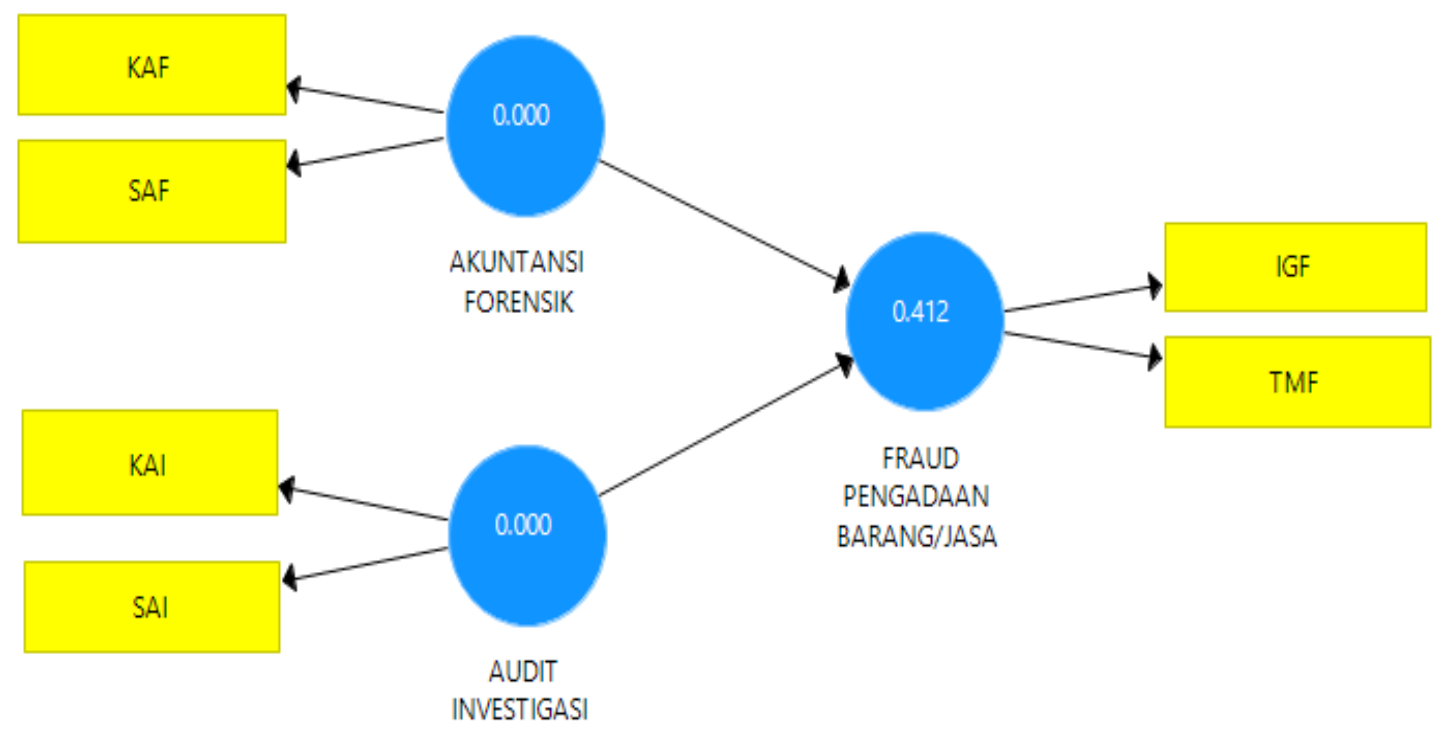

Gambar 1. Predictive Relevance

Sumber: Pengolahan data dengan SmartPLS versi 3.2.8, 2020 
Berdasarkan Gambar 1 diatas yang menunjukkan bahwa dari hasil Blindfolding Calculation nilai predictive relevance menurut data responden pada variabel Fraud Pengadaan Barang dan Jasa sebesar 0,412 menunjukkan bahwa variabel akuntansi forensik (X1) dan variabel audit investigasi (X2) memiliki relevansi prediktif yang besar pada variabel pendeteksian Fraud Pengadaan Barang dan Jasa.

\section{Pengujian Hipotesis}

Pengujian hipotesis dilakukan dengan melihat path coefficient dengan menggunakan prosedur bootstrapping. Parameter signifikansi yang di estimasi ini akan memberikan informasi mengenai hubungan antara variabel penelitian. Tabel 8 dan Gambar 2 berikut menunjukkan hasil bootstrapping sebagai dasar yang digunakan dalam menguji hipotesis dengan melihat output uji hipotesis.

Table 8. Path Coefficient Bootstrapping

$\begin{array}{cccccc}\text { HIPOTESIS } & \begin{array}{c}\text { Original } \\ \text { Sample }\end{array} & \begin{array}{c}\text { Sample } \\ \text { Mean } \\ (\mathrm{O})\end{array} & \begin{array}{c}\text { Standard } \\ \text { Deviation }\end{array} & \begin{array}{c}\text { T Statistics } \\ (\text { STDEV) }\end{array} & \text { (|O/STDEV } \mid)\end{array} \quad$ P Values

Akuntansi Forensik ->

$\begin{array}{llllll}\text { Fraud Pengadaan } & 0,302 & 0,311 & 0,126 & \mathbf{2}, 401 & \mathbf{0 , 0 1 7}\end{array}$

Barang/Jasa

Audit Investigasi ->

Fraud Pengadaan

Barang/Jasa

$\begin{array}{lllll}0,591 & 0,588 & 0,130 & \mathbf{0}, 000\end{array}$

Sumber: Pengolahan data dengan SmartPLS versi 3.2.8, 2020

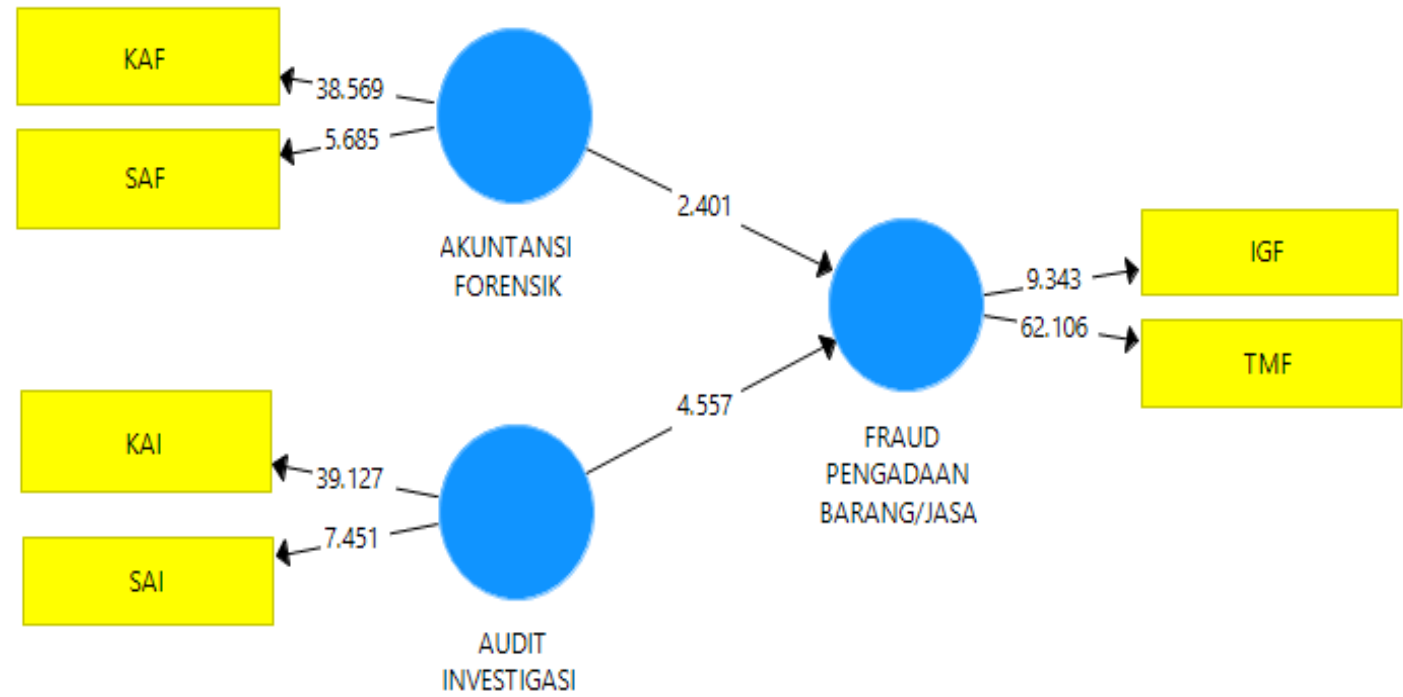

Gambar 2. Bootstrapping Model

Sumber: Pengolahan data dengan SmartPLS versi 3.2.8, 2020

Dalam penelitian ini pengukuran signifikansi pada hipotesis $\mathrm{H}_{1}$ dan $\mathrm{H}_{2}$ menggunakan cara, dengan membandingkan antara nilai $t$-tabel dan $t$-statistic. Pada penelitian ini menggunakan tingkat keyakinan sebesar 95\%, sehingga tingkat presisi atau batas tidak keakuratan sebesar $(\alpha)=5 \%$ atau kurang dari 0,05 , dengan menghasilkan nilai t-tabel 
sebesar 1,96. Jika t-statistic lebih tinggi dibandingkan dengan nilai $t$-tabel berarti hipotesis tersebut diterima. Hasil pengujian bootstrapping dengan analisis PLS yaitu sebagai berikut:

Pengujian Hipotesis 1: Penerapan Akuntansi forensik memiliki pengaruh dalam mendeteksi fraud pengadaan barang/jasa

Berdasarkan hasil pengujian yang menunjukkan nilai $t$-statistic lebih besar dibandingkan dengan kriteria nilai t-tabel yaitu sebesar $2,401>1,96$. Dengan nilai $p$-value lebih kecil dari kriteria $p$-value yaitu sebesar 0,017 $<0,05$. Sehingga dapat disimpulkan bahwa penerapan akuntansi forensik memiliki pengaruh signifikan positif terhadap pendeteksian fraud pengadaan barang dan jasa, hasil pengujian hipotesis tersebut berarti sesuai dengan hipotesis penelitian ini dimana penerapan akuntansi forensik berpengaruh dalam mendeteksi fraud pengadaan barang dan jasa. Hal itu menunjukkan bahwa hipotesis $\mathbf{H}_{1}$ diterima. Artinya auditor bidang investigasi di BPKP DKI Jakarta merasa perlu adanya penerapan akuntansi forensik yang mencakup implementasi dari kualitas akuntansi forensik dan standar akuntansi forensik yang berpengaruh positif dalam upaya meningkatkan keberhasilan pendeteksian fraud pada pengadaan barang dan jasa.

Hal ini didukung oleh hasil penelitian sebelumnya yang dilakukan oleh (Okoye \& Gbegi, 2013) yang menyatakan bahwa Penerapan akuntansi forensik secara signifikan berpengaruh terhadap berkurangnya kasus-kasus fraud yang terjadi di sektor publik. Penerapan Akuntansi forensik dapat membantu lebih baik dalam upaya pencegahan dan pendeteksian fraud di organisasi sektor publik. Selain itu penelitian yang dilakukan (Wawolangi, 2014) hasil penelitiannya juga menunjukkan bahwa penerapan akuntansi forensik sangat dibutuhkan dengan upaya utama mendeteksi fraud, dan masyarakat sudah mulai merasakan pentingnya penerapan akuntansi forensik demi kelangsungan dan pengembangan ekonomi negara Indonesia. Akuntan forensik dapat mendeteksi penyebab terjadinya kecurangan. Terdapat tiga kategori utama kecurangan yaitu korupsi, asset misappropriation, dan kecurangan laporan keuangan. Ketiga kategori kecurangan ini menimbulkan kerugian bagi negara dan keuangan negara (Jumansyah, 2011).

Pengujian hipotesis 2: Penerapan Audit investigasi memiliki pengaruh dalam mendeteksi fraud pengadaan barang/jasa

Berdasarkan hasil pengujian yang menunjukkan nilai $t$-statistic lebih besar dibandingkan dengan kriteria nilai $t$-tabel yaitu sebesar $4,557>1,96$. Dengan nilai $p$-value sebesar 0,000 lebih kecil dari kriteria $p$-value yaitu sebesar $0,000<0,05$. Sehingga dapat disimpulkan bahwa penerapan audit investigasi memiliki pengaruh signifikan positif terhadap pendeteksian fraud dalam pengadaan barang/jasa, hasil pengujian hipotesis tersebut berarti sesuai dengan hipotesis penelitian ini dimana penerapan audit investigasi berpengaruh dalam mendeteksi fraud pengadaan barang dan jasa. Hal itu menunjukkan bahwa hipotesis $\mathbf{H}_{2}$ diterima. Artinya auditor bidang investigasi di BPKP DKI Jakarta merasa perlu adanya penerapan audit investigasi yang mencakup implementasi dari Kemampuan/keahlian Audit investigasi dan standar audit investigasi yang berpengaruh positif dalam upaya meningkatkan keberhasilan pendeteksian fraud pada pengadaan barang dan jasa.

Hal ini sesuai dengan hasil penelitian sebelumnya yang dilakukan oleh (Mamahit, 2018) yang menyatakan bahwa Penerapan Audit investigasi bertujuan untuk membuktikan apakah fraud telah benar terjadi atau tidak. Setelah dilakukan audit investigasi, hasil yang diperoleh adalah berupa kesimpulan apakah tindakan fraud benar terjadi yang digambarkan dengan rangkaian proses kejadiannya atau kesimpulan bahwa tindakan fraud tidak terjadi. Selain itu, penelitian yang dilakukan (Ardiansyah et al., 2016) menunjukkan bahwa Audit investigasi berpengaruh signifikan terhadap pendeteksian fraud, Penerapan Audit investigasi yang semakin baik dapat meningkatkan ketepatan akan pendeteksian fraud.

\section{Simpulan dan Saran}

Berdasarkan analisis dan pembahasan pada bagian sebelumnya, maka dapat ditarik kesimpulan dari pengujian yang telah dilakukan menunjukkan bahwa, penerapan akuntansi forensik memiliki pengaruh signifikan terhadap pendeteksian fraud pengadaan barang dan 
jasa, maka dengan penerapan akuntansi forensik yang semakin baik, akan berpengaruh positif dan dapat meningkatkan upaya keberhasilan dalam mendeteksi fraud pengadaan barang dan jasa, dan penerapan audit investigasi memiliki pengaruh signifikan terhadap pendeteksian fraud pengadaan barang dan jasa, maka dengan penerapan audit investigasi yang semakin baik, akan berpengaruh positif dan dapat meningkatkan upaya keberhasilan dalam mendeteksi fraud pengadaan barang dan jasa.

Selain itu, penelitian yang dilakukan ini tidak dapat terlepas dari beberapa keterbatasan. Berikut merupakan beberapa keterbatasan dan saran-saran yang dapat diberikan sebagai berikut: Penelitian ini memiliki keterbatasan yang melekat dikarenakan penelitian ini menggunakan data primer yang diperoleh melalui kuesioner, yaitu kemungkinan terjadi perbedaan persepsi antara peneliti dan responden karena responden dan peneliti tidak dapat saling mengklarifikasi pertanyaan atau pernyataan. Oleh karena itu penelitian tentunya menjadi lebih representatif apabila mengombinasikan dengan metode wawancara sehingga persepsi responden atas pertanyaan atau pernyataan dapat diketahui secara mendalam. Selain itu, penelitian ini hanya menggunakan sampel auditor pemerintah di bidang investigasi yang bekerja pada Badan Pengawasan Keuangan dan Pembangunan Provinsi DKI Jakarta sehingga hasil dan kesimpulan penelitian ini tidak dapat digeneralisasi untuk seluruh auditor bidang investigasi di bagian wilayah Indonesia lainnya. Penelitian selanjutnya diharapkan memperluas wilayah cakupan sampel yang sehingga diperoleh hasil penelitian dengan tingkat generalisasi yang lebih tinggi.

Adapun saran yang dapat penulis sampaikan adalah, penelitian selanjutnya disarankan untuk menambah objek dan responden penelitian, serta diharapkan dapat menambah luas populasi dan sampel penelitian untuk hasil yang lebih baik, selain itu penelitian sejenis selanjutnya perlu melakukan pengujian faktor-faktor lain yang mungkin dapat mempengaruhi pendeteksian fraud pengadaan barang dan jasa. Untuk mendapatkan kualitas data dan hasil yang lebih baik, disarankan instrument penelitian tidak hanya menggunakan kuesioner, namun juga wawancara dan survey, untuk mendapatkan data yang lebih nyata, serta diharapkan bagi peneliti selanjutnya, agar dapat menambah dan mengembangkan model yang lebih banyak melibatkan variabel indikator dan variabel laten lainnya yang berkaitan dengan akuntansi forensik, audit investigasi, ataupun fraud pengadaan barang dan jasa.

\section{Daftar Rujukan}

Anti-Corruption Clearing House. (2019). Tindak Pidana Korupsi Berdasarkan Perkara. Retrieved November 11, 2019, from acch.kpk.go.id website: https://www.kpk.go.id/id/statistik/penindakan/tpk-berdasarkan-perkara

Ardiansyah, A., Purnamasari, P., \& Gunawan, H. (2016). Penerapan Akuntansi Forensik dan Audit Investigasi terhadap Pendeteksian Fraud Asset Misappropriation ( Studi Kasus pada Badan Pengawasan Keuangan dan Pembangunan Pusat ). 695-701.

Association of Certified Fraud Examiners Indonesia Chapter. (2016). Suvey Fraud Indonesia. Jakarta.

Fauzan, I. A., Purnamasari, P., \& Gunawan, H. (2014). Pengaruh Akuntansi Forensik dan Audit Investigasi terhadap Pengungkapan Fraud. Penelitian Sivitas Akademika Unisba (Sosial Dan Humaniora), 2(2), 456-465.

Karyono. (2013). Forensic Fraud (I). Yogyakarta: C.V ANDI OFFSET.

Lembaga Kebijakan Pengadaan Barang/Jasa Pemerintah. (2010). Modul Pelatihan Pengadaan Barang/Jasa Pemerintah.

Nurharjanti, Nisa. (2017). Faktor-Faktor yang Berhubungan dengan Fraud Pengadaan Barang/Jasa di Lembaga Publik. Jurnal Akuntansi Dan Investasi, 18(2), 209-221. 
https://doi.org/10.18196/jai.180284

Nur, Ilmi Faisal, Morasa Jenny, dan L. M. M. (2017). Analisis Sistem Pengadaan Barang Dan Jasa (Penunjung Langsung) Pada Di Dinas Pekerjaan Umum Dan Penataan Ruang Kota Manado. Jurnal Riset Akuntansi Going Concern, 12(2), 1122-1132.

Okoye, E. I., \& Gbegi, D. O. (2013). Forensic Accounting: A Tool for Fraud Detection and Prevention in the Public Sector. (A Study of Selected Ministries in Kogi State). International Journal of Academic Research in Business and Social Sciences, 3(3), 2222-6990.

Patunru, A. L. (2015). Pengaruh Kemampuan Auditor Investigatif Terhadap Efektivitas Pelaksanaan Prosedur Audit Dalam Pengungkapan Internal Fraud. In Statewide Agricultural Land Use Baseline 2015 (Vol. 1). https://doi.org/10.1017/CBO9781107415324.004

Rizki, B. F., Purnamasari, P., \& Oktaroza, M. L. (2017). Pengaruh Akuntansi Forensik dan Audit Investigasi terhadap. Prosiding Akuntansi, 421, 513-524.

Tuanakotta, T. M. (2016). Akuntansi Forensik \& Audit Investigasi-Edisi 2 (2nd ed.). Salemba Empat.

Wiralestari. (2016). Fraud: Akuntansi Forensik dan Audit Investigatif. Media Riset Akuntansi, $6(1), 43$.

Wiratmaja, I. D. N. (2017). Akutansi Forensik Dalam Upaya Pemberantasan Tindak Pidana Korupsi. Al Daulah: Jurnal Hukum Pidana Dan Ketatanegaraan, 6(2), 199-205. https://doi.org/10.24252/ad.v6i2.4876 